\title{
La capilla de la Virgen de Campanar en Valencia: tradición popular erigida en erudita retórica visual
}

\author{
Rafael García Mahíques \\ Universidad de Valencia \\ rafael.g-mahiques@uv.es
}

RESUMEN: Esta capilla forma parte de la iglesia parroquial de Campanar, perteneciente al municipio de Valencia. La Virgen de Campanar es una imagen realizada en alabastro, hallada el día 19 de febrero de 1596 en el subsuelo de la iglesia de esta localidad por unos albañiles en el momento de practicar unas obras. Comenzó a partir de entonces a ser venerada popularmente como una imagen milagrosa. Entre sus particularidades, se cuenta el misterioso hecho de que el polvo desprendido de su masa tuviese propiedades milagrosas: se tomaba disuelto en agua para curar a los enfermos o para que las embarazadas tuviesen un buen parto, e incluso calmaba tempestades si era arrojado al mar por quienes se habían embarcado. Estos polvos eran extraídos de la imagen mediante un raspado practicado ritualmente por el sacerdote. Tanto las circunstancias de su hallazgo, como la particular virtud de dichos polvos, constituyen las claves de un complejo programa visual de carácter emblemático, desplegado pictóricamente en las bóvedas de la capilla que alberga la imagen. El presente estudio aborda el análisis e interpretación iconográfica de este programa.

PALABRAS CLAVE: Virgen de Campanar; Programa visual; Jeroglíficos; Emblemática; Milagros.

\section{The Chapel of the Virgin of Campanar in Valencia: Popular Tradition Elevated in Erudite Visual Rhetoric}

ABSTRACT: This chapel forms part of the parochial church of Campanar, which belongs to the municipality of Valencia. The Virgen de Campanar (Virgin of Campanar) is an image executed in alabaster, discovered on the subfloor of the church of this place on February 19th, 1596, by some construction workers who were undertaking some remodeling at that time. From that moment forward it began to be worshipped by the masses as a miraculous image. Among its alleged properties we find the mysterious fact that powder from its plaster had miraculous effects: it was taken dissolved in water to cure the sick or to assure a healthy birth for pregnant women, and it even calmed storms at sea if it was thrown into the water by those who had set sail. These powders were extracted from the image by means of a ritualistic filing by a priest. Both the circumstances surrounding its discovery, as well as the unique virtues of the powders, constitute the keys to interpreting a complex visual program of an emblematic nature that is pictorially displayed in the vaults of the chapel that houses the image. This study undertakes the analysis and iconographical interpretation of this program.

KEYWORDS: Virgin of Campanar; Visual Program; Hieroglyphs; Emblematics; Miracles.

José de Castellví Coloma, marqués de Villatorcas, noble valenciano, recorrió durante varios años, durante el siglo XVII los principales santuarios y capillas marianas del antiguo reino y fue anotando los datos sobre los hallazgos y demás circunstancias de las imágenes más veneradas, con una indudable óptica histórica y documental, usando un lenguaje claro y sencillo, y apartándose de todo relato legendario. Tras su muerte (1722) su biblioteca quedó dispersa, y el manuscrito citado, con sus últimas anotaciones de 1689, terminó en la biblioteca real en tiempos de Carlos IV, donde actualmente se conserva. La Virgen de Campanar [1] es una imagen en altorrelieve -aunque tratada para la veneración como una imagen exenta, a la que incluso se le dispone un manto-, realizada en alabastro, hallada en el subsuelo de la iglesia por unos albañiles en el momento de practicar unas obras el día 19 de febrero de 1596. Villatorcas nos transmite con todo detalle este acontecimiento, siendo

Cómo citar este artículo: GARCÍA MAHÍQUES, Rafael, «La capilla de la Virgen de Campanar en Valencia: tradición popular erigida en erudita retórica visual», Boletín de Arte-UMA, n. ${ }^{\circ}$ 39, Departamento de Historia del Arte, Universidad de Málaga, 2018, pp. 31-47, ISSN: 0211-8483, DOI: http://dx.doi.org/10.24310/BoLArte.2018.v0i39.5248 


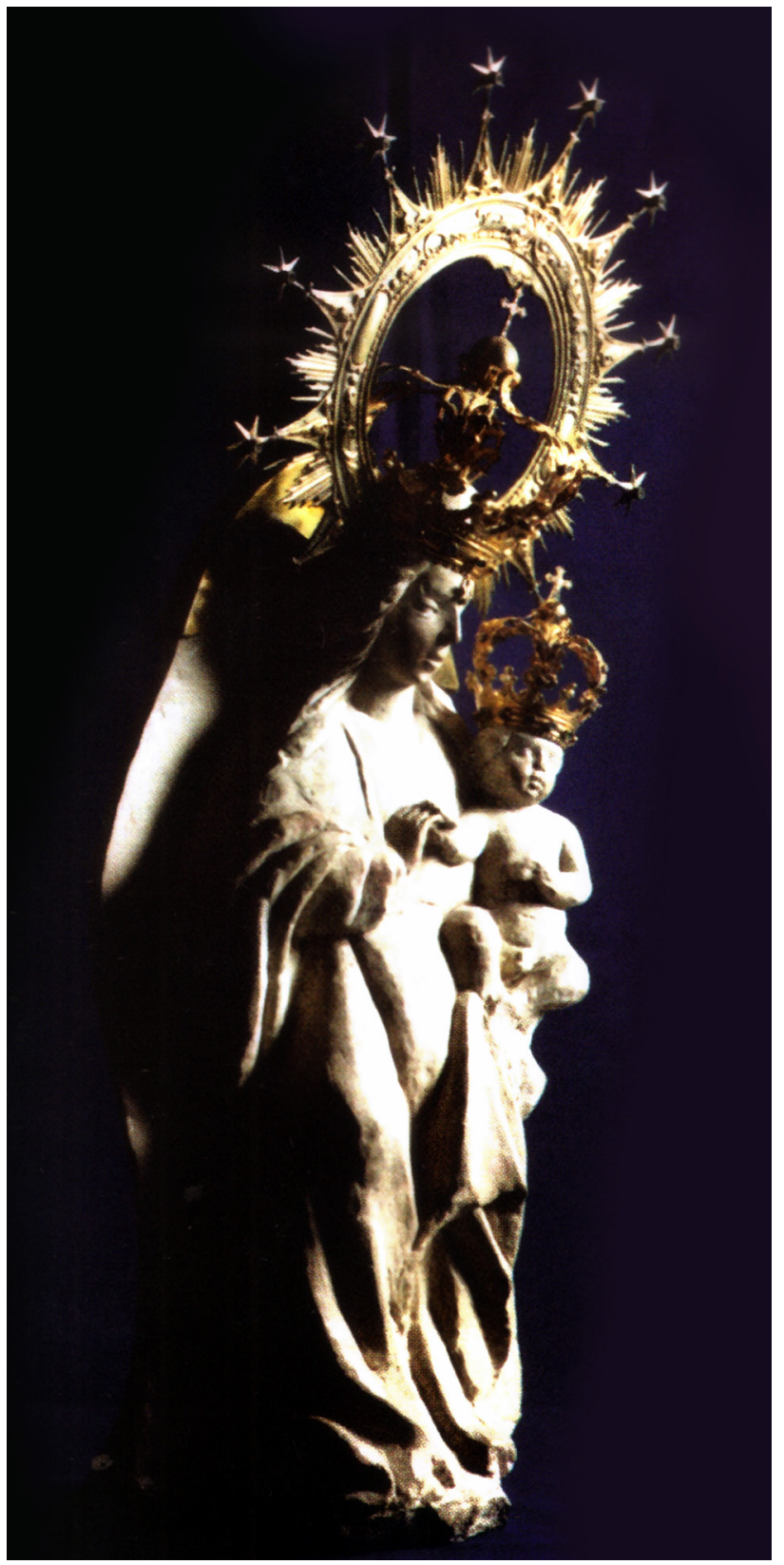

1. Imagen de la Virgen de Campanar

probablemente esta la versión más verosímil, y quizás la más antigua que existe:

Fabricavase en la Iglesia Parroquial del lugar de Campanar una sepultura para los clérigos, y haviendose ya casi acabado la sepultura quisieron recoger los albañiles los niveles que estaban dentro de ella, para cuyo efecto imbio el maestro un oficial, y aunque este los tenia delante los ojos no los halló haviendo bajado dos vezes, pero instado por tercera vez al bajar se resvaló en un escalon y dio en un tabique que al golpe se abrió y descubrió un nicho, a donde se halló la S. ${ }^{\text {ta }}$ Imagen, y assi que vio esta soberana $G{ }^{2}$ vio los niveles, y todos los Instrumentos que buscaba de su oficio. Sacaron de allí la Imagen, y la colocaron en el Altar que hoy está, y en donde obra particulares milagros y favores con los que se valen de su patrocinio y amparo (Castellví, 1689: 21).

A continuación el autor ofrece datos sobre su hallazgo, sus dimensiones y su materia: «piedra blanca como de alabastro». También da cuenta de una de las particularidades de esta imagen a nivel de la devoción popular: el ser raspada para obtenerse polvo con propiedades milagrosas: «y continuamente se saca tierra de la Imagen con abundancia para dar a los enfermos, sin que nunca se conozca menoscabo, y con ella obra la Divina Mag. ${ }^{d}$ muchos y prodigiosos milagros» (Castellví, 1689: 21). Hasta aquí tenemos ya los principales elementos que configurarán el programa emblemático de su capilla, objeto del presente estudio. Castellví continuará dando cuenta de otras informaciones, como las ropas y los enseres relativos a la imagen: mantos, coronas, lámparas, joyas, etc., así como las fiestas que se le dedican (1689: 21 y 22).

Es esencial, en cuanto al programa del que nos vamos a ocupar, el asunto de los polvos extraídos del rascado posterior de la imagen. Esta costumbre pervivió durante siglos, y nos la describe perfectamente el párroco Bartolomé Combes, quien nos ha dejado una obra célebre, que nos servirá de fuente y guía principal para entender dicho programa (Combes, 1714). Este eclesiástico se refiere a estos polvos del siguiente modo: «(...) la qual deshecha en POLVOS, comunica perennes Beneficios por todo el Orbe, según lo atestigua el nunca bastantemente ponderado Favor, y Portento de la TIERRA fértil, que, como de Fuente inagotable, sus propias espaldas nos franquean, sin disminución, ni quiebra de su Santo Bulto» (Combes, 1714: 75). Dedicará además el capítulo III de su obra (77 y ss.) al pormenor de estos polvos. Aquí se refiere al modo con que son obtenidos los polvos de la imagen, habida cuenta que primitivamente se arrancaban trozos y se machacaban para convertirlos en polvo: «antiguamente era tanta la frequencia, y abuso que se hazia, que como si la Imagen fuera vn basto Monte abreviado, en ocasión alguna 
con vn escoplo, y Martillo, le quitaban crecidos pedaços de su Santo Bulto, quebrantándolos después en Polvos (...)» (1714: 79-80). Explica el modo como se reguló, sin permitirse que seglar alguno practicara el lacerado de la imagen:

Siempre que se necesita de TIERRA para repartir entre los Fieles Devotos de MARIA Santissima Señora nuestra, se ponen sobre la Mesa del Altar, y Retablo de la Imagen, dos luzes, vna à cada lado, y el Cura, ò qualquier de los Eclesiasticos residentes de la Iglesia, con Roquete, y Estola revestidos, suben al Nicho de la Santa Imagen, y dando vuelta al Trono en que reside, apartan el precioso Manto, que orinariamente la adorna, quedando descubiertas las Espaldas: a este tiempo con vn cuchillo limpio, y azerado, raen poco à poco las Espaldas mesmas, y como en raudales de lluvia, se ven desatarse en atomos de TIERRA muy menuda, la qual con gran Veneracion, y sumo aprecio se recibe sobre vn pliego de papel, que para este efecto se acomoda baxo (Combes, 1714: 80.81).

La sacralidad mistérica desprendida de este hecho prodigioso, llega a tener unos matices interpretativos muy esmerados, como puede ser el hecho de que por el lado derecho sea más blando que el izquierdo para el desprendimiento de las limaduras:

No se duda en que los dà por todas partes, mas con grande escasez los comunica, resistiéndose fuertemente de este lado: O, porque estando el Templo en donde habita, consagrado à la Virgen Madre, baxo el inefable Titulo, è Invocacion de su gran Misericordia, simbolizada en el lado derecho; quiere dar a entender a sus Devotos, que por este lado se deshace toda a favor suyo, y que es de sobra buscar el recurso en otra parte: O, porque correspondiendo el Niño Jesvs, que està en sus Braços al lado Izquierdo, parece, que se dà por muy sentida de que allí la toquen, y el que à su amantísimo Hijo, se ofenda en cosa alguna. Sea lo que fuere, entiendo, que el sucesso no carece de misterio grande (Combes, 1714: 83-84).

El modo de ser consumidos estos polvos es a través de la bebida. Lo atestigua de este modo el párroco de Campanar:

El modo, pues, de valerse, y vso de estos POLVOS consiste, y es lo mas regular tomarles en Bevida, de qualquier genero que sea, poniendo en ella la tènue porcion de vn Papelillo (como es costumbre repartirse, en esta forma, siempre que se piden) implorando antes de tomarse, el poderoso Amparo, y Proteccion de la que es Madre de la Vida, y Salud de todo el Orbe, MARIA Santissima Señora Nuestra, esperançando indispensablemente, el buen logro de la felizidad que se desea (Combes, 1714: 89-90).

Mas por muy afectada que a ojos actuales pueda parecernos toda esta historia, Combes no cae en cierta heterodoxia idolátrica, y justifica espiritualmente el fenómeno: María se vale de estos polvos «no porque estos polvos tengan es sì virtud, para el remedio, y Salud que busca el desvalido, sino para acreditar, por su medio, el poder de sus Milagros, en todos aquellos, que con ardiente fè les vsan» (Combes, 1714: 89).

\section{Localización histórica de la Capilla}

La capilla está conformada en tres tramos, el primero con bóveda vaída, el segundo con cúpula sobre tambor y pechinas, y el tercero, correspondiente al presbiterio también con bóveda vaída. Sobre la cronología de esta capilla, el citado Bartolomé Combes nos informa que su configuración arquitectónica, así como el retablo, fueron dispuestos en el siglo XVII: «fue renovada el año de MIL SEISCIENTOS Y CINQVENTA, por un Devoto Parroquiano; y el de MIL SEISCIENTOS SESENTA Y CINCO, à Devocion, y Expensas de algunos particulares, se le costeò vn Retablo de admirable Architectura, con vn Ostentoso Nicho, y en èl vn Trono de Serafines, sobre vnas Nubes, perfectamente entallados, donde oy, como en Cielo hermoso se eterniza» (Combes, 1714: 73). Cabe suponer que dicha configuración arquitectónica de 1650 sería la actual, no así del retablo, ya que el actual es obra del s. XX. Con todo, nada nos dice Combes sobre estas pinturas murales, lo que nos haría suponer que debieron ser ejecutadas con posterioridad a 1714. Es evidente que de haberse pintado anteriormente, el propio Combes hubiera destinado algún comentario a ellas, o al menos alguna alusión. Es más, como vamos a comprobar a continuación, los jeroglíficos de la cúpula no se entienden sino inspirados en el citado libro de Combes, o bien haya sido el propio Combes quien inspirara dicho programa en tiempo no muy anterior a 


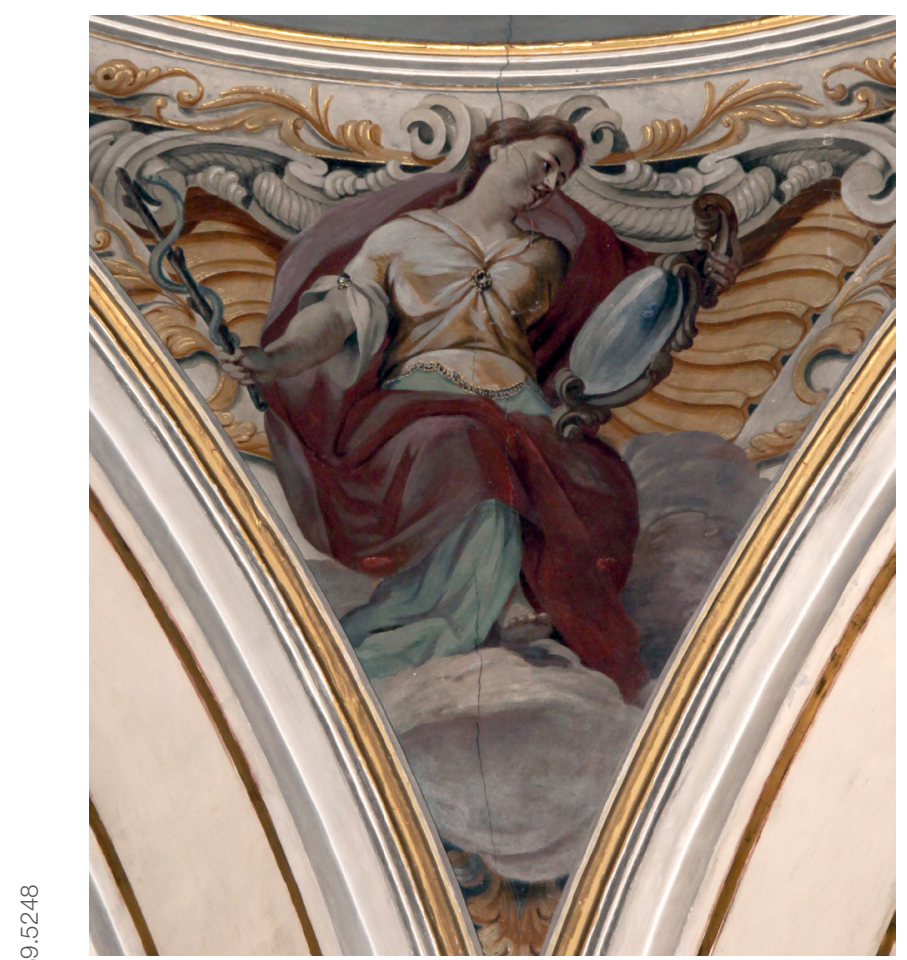

2. La Prudencia

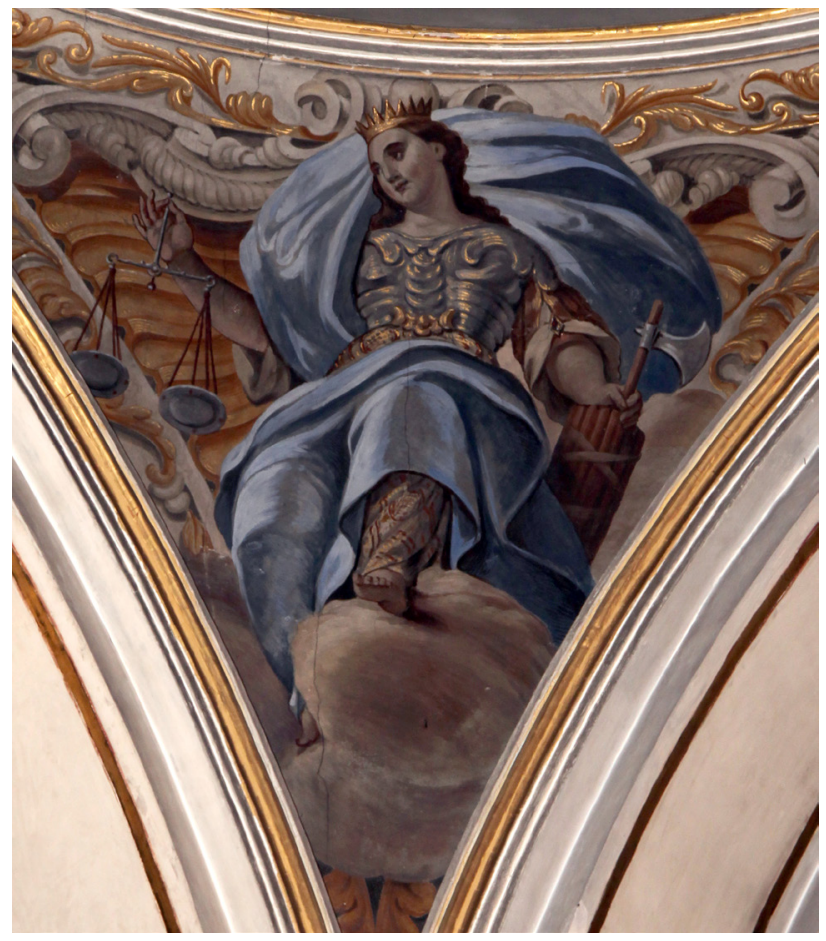

3. La Justicia
1714 y próximo a la composición e impresión de su libro. Las fuentes dieciochescas -Orellana, Ceán Bermúdez- no mencionan tampoco la obra pictórica de esta capilla, y en cambio sí lo hacen de la del trasagrario, un ámbito mucho más conocido (Benito, 1982), como obra del pintor Donís Vidal, discípulo de Palomino y autor así mismo de otros programas visuales, como el de la iglesia de San Nicolás de Valencia. En el orden estilístico no cabe duda de que existe una vinculación entre ambos conjuntos: trasagrario y capilla. En algún detalle, como los ángeles infantes portadores de ramos, se revela una clara dependencia de la obra de Palomino en la Basílica de la Virgen de los Desamparados, realizada entre 1701 y 1704. Podemos, pues, concluir con que esta obra es atribuible a Donís Vidal, o a su taller. Debe ser tenido en cuenta también, que si damos por válido que las pinturas se realizan con posterioridad a 1714, o en torno a esta fecha, se trataría de una de las últimas obras de Donís Vidal, ya que este murió en torno a 1720 en Tortosa a donde se desplazó para pintar en la capilla de la Virgen de la Cinta.

\section{Los jeroglíficos de la cúpula}

En la bóveda del primer tramo, un ángel sostiene una filacteria en la que se avisa de que aquél es un lugar sagrado: VERE HIC NON EST ALIVD, NISI DOMVS DEI, ET PORTA COELI [En verdad no es este un lugar cualquiera, sino la casa de Dios y la puerta del Cielo]. Una «M» de María ocupa también el centro del luneto frontal interior de esta capilla.

El segundo tramo, está coronado con cúpula sobre pechinas, en donde se disponen las personificaciones alegóricas de las cuatro virtudes cardinales: Prudencia, Justicia, Fortaleza y Templanza. Nos detendremos solamente en su breve descripción, por conformarse con una disposición y unos atributos muy conocidos y estudiados ${ }^{1}$. La Prudencia [2] dirige su mirada a un espejo que sostiene en su mano izquierda, mientras levanta en su derecha un bastón en el que se enrosca la rémora. La Justicia [3] es una matrona coronada, vestida con armadura y manto azul, que porta en su mano derecha una balanza, y tiene a su izquierda las fasces con el hacha. La Fortaleza [4] es también una matrona vestida con armadura y tocada con yelmo, que abraza una columna. La Templanza [5] es también una joven con manto verde que trasvasa el líquido de una jarra a una copa. 
En los gallones de la cúpula, bajo una linterna fingida pictóricamente, se dispone un conjunto de ocho jeroglíficos [6]. Mas no se trata de símbolos letánicos corrientes, ya que se refieren a aspectos significantes concretos de la imagen de la Virgen de Campanar, los cuales parecen inspirados, en su mayor parte, en el citado libro de Bartolomé Combes, más el prólogo de este a cargo de Vicente Bellmont, trinitario del Convento del Remedio de Valencia, el cual lleva por título «Elogio que a la Virgen Santissima de Campanar, à su Libro, y à su Autor (...)» (sin nº de pp.). Se trata de símbolos en gran parte basados en fuente bíblica $y$, en general, con precedentes de diversa índole en la tradición emblemárica, pero conformando en su conjunto un discurso visual coherente.

Jeroglífico l: el Ara

El que podríamos considerar como primero de ellos consiste en un ara humeante con el mote "Altare sacrum" [altar sagrado]. Su significado viene dado por las circunstancias del hallazgo de la imagen: sobre un ara, hecho prefigurado con el descubrimiento del fuego de los holocaustos por Nehemías. Así, se narra en el segundo libro de los Macabeos (2 M,18 y ss.), que ante la deportación, los sacerdotes tomaron fuego del altar que escondieron secretamente en un pozo seco, y dicho fuego será rescatado por Nehemías en forma de un líquido espeso con que rociaron la leña y prendió. En relación con este pasaje, dice así Combes: «(...) y a poca diligencia encontró con el impensado Tesoro del Divino, y Arcano Simulacro de MARIA Santissima Señora nuestra, que estaba sobre una ARA, como quien gustosamente se ofrecia en Sacrificio, para remedio de las miserias Humanas, EN PIE, qual firmissima Columna de luz inextinguible, para Norte seguro de los Fieles, mejor que aquella (Exodi 13, vers. 21) que guiò por el desierto à los Hebreos» (1714: 65). El sentido de este jeroglífico se entiende mejor si se considera la leyenda -común también a otras imágenes «encontradas»según la cual la imagen fue escondida en tiempo de la invasión musulmana de la Península. Con palabras de Combes: «porque reconociendo próxima la entrada del cruel Invierno de la furia Mahometana, y Sarracena, por no exponer al vltraje de tan vil canalla, su Divina Imagen, mientras durò lo tempestuoso de tan infeliz Reynado (...) estuvo allí oculta

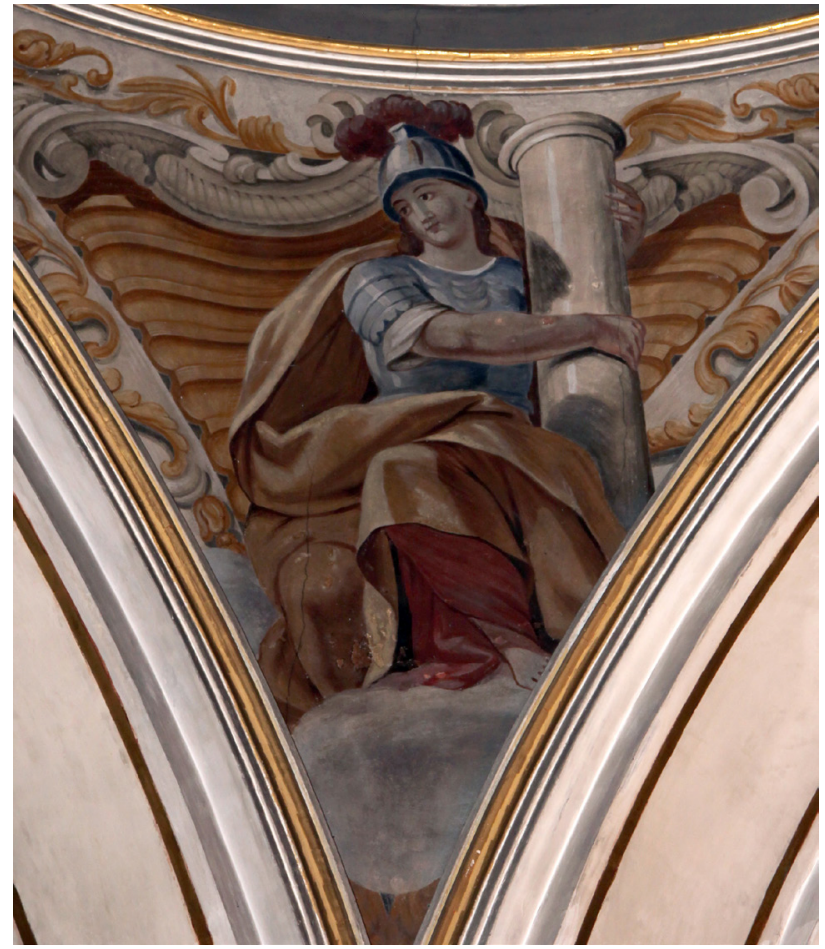

4. La Fortaleza

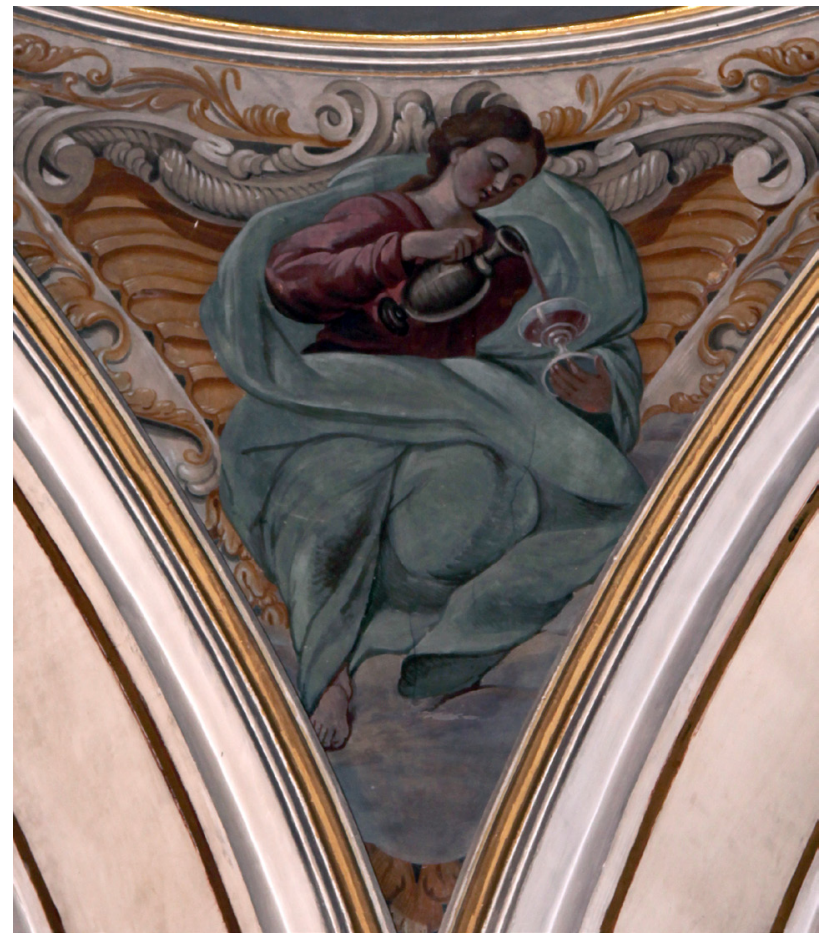

5. La Templanza 
ochocientos ochenta, y dos años discurridos, hasta el dia de su felizisimo Hallazgo (...)» (1714: 57).

Jeroglífico II: la Columna de luz

Justamente, la columna de luz en la cita de Combes que acabamos de considerar: "EN PIE, qual firmissima Columna de luz inextinguible», constituye el asunto del segundo de los jeroglíficos. Consta de una columna envuelta de un aura, bajo el mote: «Columna lucis» [columna de luz]. Toma como referencia la columna de luz del paso de los israelitas por la península del Sinaí: "Yahvé iba al frente de ellos, de día en columna de nube para guiarlos por el camino, y de noche en columna de fuego para alumbrarlos, de modo que pudiesen marchar de día y de noche» (Ex 13,21). Este pasaje bíblico tiene también su versión emblemática en el jeroglífico de la obra de Nicolás de la Iglesia dedicada a la Inmaculada Concepción, el cual lleva por mote: «Columna ignis, \& nubis», por pictura la columna luminosa encima del mar Rojo con los restos del ejército faraónico anegado, y un epigrama que reza: «Por entre aquesta columna / Mirò Dios para anegar / A Pharaon en el mar» (1659: 65b).

Jeroglífico III: la Aurora

Una aurora, con el mote «Aurora vald(e) rutilans» [aurora muy brillante] conforma el siguiente jeroglífico. La Aurora es un recurso retórico procedente de los Cantares, en donde el Esposo habla de la Esposa de este modo: «Quae est ista, quae progreditur quasi aurora consurgens?» [Quien es esta que surge cual la Aurora?] (Ct 6,10). La tradición exegética entiende a la Esposa por la Iglesia, y también por María, que por su parte es también imagen de la Iglesia. En la emblemática, un ejemplo de la utilización de este recurso lo tenemos también en los jeroglíficos de Nicolás de la Iglesia, en donde leemos en su epigrama: "No à de auer obscuridad / al tiempo que se leuanta / Esta aurora Sacrosanta» (1659: 43v).

Para entender el sentido que este jeroglífico adquiere en Campanar, debe ser tenido en cuenta que el hallazgo de la imagen en 1596 coincide con el punto álgido del problema morisco, que acabó resolviéndose con la expulsión en 1609. Bartolomé Combes se hace eco de ello señalando el acontecimiento y reconociendo el papel desempeñado en este hecho por el Patriarca Juan de Ribera. Define dicho acontecimiento como una «aurora» tras haberse despejado el cielo de nubes muy densas. Dicha aurora es María. Así se expresa: «(...) cuyo total exterminio se consiguió el año mil seiscientos, y nueve, no tanto por el zelo Santo y Religioso de tan gran Prelado, digno de memoria eterna, como por la poderosa Intercession de esta Divinissima Señora, que anunciando el destierro de tan densas Nubes, como nos circuian, amaneció à este tiempo, qual brillante Aurora, Precursora de nuestras mayores felizidades» (1614: 68).

Jeroglífico IV: la Luz

El siguiente jeroglífico presenta un candelero encendido, con el lema: «Indeficiens lumen» [luz indeficiente]. Su sentido parece vincularse también con las circunstancias del hallazgo de la imagen, el cual se produce justamente en el lugar que iba destinado a ser tumba de eclesiásticos. Combes se refiere al habitáculo de María durante los siglos de la «infeliz pérdida de España» como un "Mausoleo de la mejor Arca Maria Santissima Señora nuestra», y que dicho espacio quedaría para siempre iluminado por su «luz indeficiente» o invariable: "despues de su asistencia y contacto debio quedar su habitación, insignemente Gloriosa: Pues esta divinissima Princessa, como Madre especial de los Sacerdotes, por haverlo sido del verdadero, y primer Sacerdote de la Ley de Gracia Christo Señor nuestro; parece que tomo a su cuenta, purificarla con el Lleno de su Luz indeficiente, desterrando los tenebrosos horrores de la muerte, para eternizar la mejor vida, en el propio lugar donde fue encontrada» (1714: 59-60).

Jeroglífico V: el Tesoro escondido

A continuación el siguiente enigma consta de una caja o un tesoro: «Thesaurvm absconditu(m)» [tesoro escondido]. Su sentido puede ir en relación con la ocultación de la imagen durante siglos, para ser encontrada en relación con la construcción de una tumba. Fr. Vicente Bellmont, prologuista del libro de Bartolomé Combes, refiere este recurso retórico del tesoro escondido: «3 (...) se descubrió, para que se experimentasen sus muchos beneficios, y Peregrinas Gracias, 


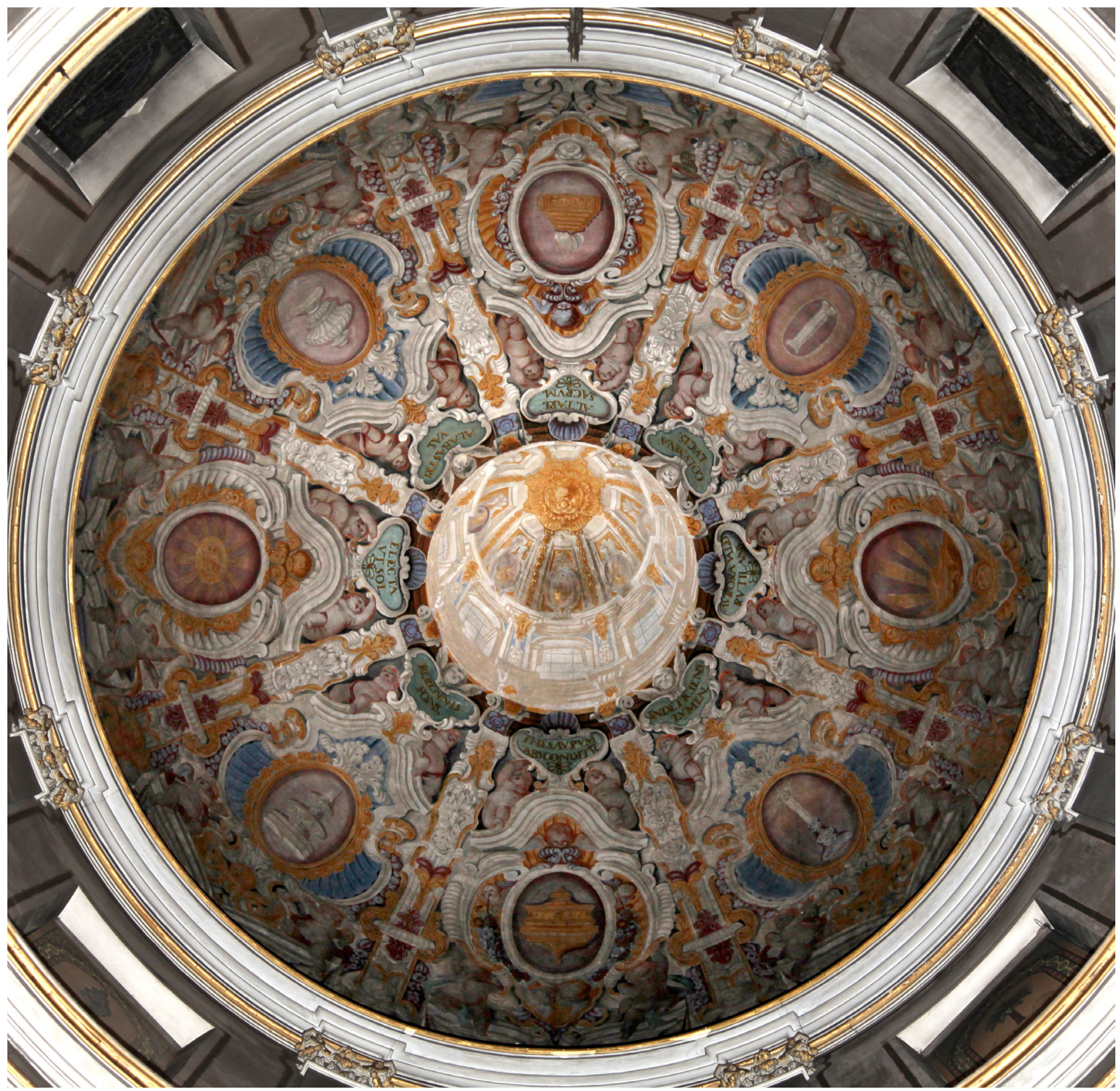

6. Jeroglíficos de la cúpula

siendo su feliz hallazgo, como el de vn rico TESORO, que deviò llenarles de Jubilo, Plazer, y Regocijo: Sicut effodientes Thesaurum, gaudent vehementer, cum invenerint Sepulchrum». La última cita corresponde al libro de Job: «Qui exspectant mortem, et non venit, et effodiunt quaerentes illam magis quam thesauros; gaudentque vehementer et laetantur sepulcro" [A los que ansían la muerte que no llega y exca- van en su búsqueda más que por un tesoro, a los que se alegran ante el túmulo y exultan cuando alcanzan la tumba» (Jb 3,20-21). Es evidente que Bellmont ha tratado -mediante un epítome del texto, o una interpretación intencionada-, de relacionar este pasaje de Job con el hallazgo de la imagen mientras los operarios trabajaban en una sepultura. No obstante, más adelante, en la respuesta que en el mismo 
libro ofrece Bartolomé Combes al «Elogio» de Vicente Bellmont, se referirá a la imagen de la Virgen como thesaurum reconditum, tomando la expresión de la evangélica parábola de tesoro en la que Cristo compara el Reino de los Cielos con un tesoro escondido en un campo que al encontrarlo un hombre, vende todo lo que tiene para comprar dicho campo (Mt 13,44). Con base a esta referencia, se expresa así Combes en relación con el recóndito tesoro de la Virgen de Campanar: "quanto V.R. ${ }^{\text {ma }}$ dize en orden al adelantamiento de las Glorias de tan Santo, y Divino Simulacro, venero como rico TESORO inapreciable; el qual para mi, que tengo la ordinaria Habitacion: In Agro. No es mucho me fuesse: Absconditum». Estos dos referentes complementarios, el del Bellmont y el de la respuesta de Combes, nos ofrecen base suficiente para la comprensión de este jeroglífico.

Jeroglífico VI: la Fuente

Un surtidor de agua y el mote «Perennis fons» [fuente inagotable], componen el siguiente jeroglífico. Fons signatus [fuente sellada] es uno de los símbolos más universales de María. Procede de los Cantares: "Hortus conclusus soror mea sponsa hortus conclusus fons signatus» [Huerto eres cerrado, hermana mía, esposa, jardín cerrado, fuente sellada] (Ct 4,12). Pero no es este el código retórico aplicado aquí. Como perennis fons no cabe duda que el asunto de este jeroglífico se orienta hacia el sentido de los inagotables beneficios que se obtienen por medio de María, en paralelo a lo inagotable de los milagrosos polvos que se sacan de su imagen de Campanar. El citado Fr. Vicente Bellmont habla de la Virgen de Campanar como «fuente indeficiente»: «12 Todo lo qual sucede en la Tierra, que de la milagrosa imagen de la Virgen de Campanar frequentemente se saca; yà en lo de no verse disminuido su Trasumpto; yà en lo de parecer como manantial FUENTE INDEFICIENTE, que nunca cessa, ni enjamàs se menoscaba».

Jeroglífico VII: el Sol

Un sol conforma la pictura del siguiente jeroglífico, que lleva por mote: «Electa vt sol» [refulgente como el sol]. Se trata aquí nuevamente de un símbolo mariano muy tradicional, cuya mayor difusión corresponde al momento en que se crea el tipo iconográfico de María como «Tota pulchra», que se desarrolla a partir de 1500 (Stratton, 1988: 34 y ss.). Su fuente es el mismo versículo citado antes en relación con la Aurora: «Quae est ista, quae progreditur quasi aurora consurgens, pulchra ut luna, electa ut sol, terribilis ut castrorum acies ordinata?» [¿quién es esta que surge cual la aurora, bella como la luna, refulgente como el sol, imponente como batallones?] (Cant 6, 10). No existe en el libro de Combes una explícita referencia a este concepto, por lo que debemos vincularlo únicamente a la tradición.

Jeroglífico VIII: el Vaso de alabastro

El último de los jeroglíficos nos muestra una copa de alabastro, con el mote: "Alabastrvm vas" [vaso de alabastro]. El frasco de alabastro tiene un referente escriturístico claro: el pasaje en que estando Cristo recostado en la mesa «vino una mujer que traía un frasco de alabastro con perfume puro de nardo de mucho precio; quebró el frasco y lo derramó sobre su cabeza» (Mc 14,3). Continúa la historia con la protesta de algunos de los presentes que consideraron tal hecho un despilfarro por parte de la mujer, a lo que el propio Jesús les recrimina. Probablemente la clave de este emblema esté en la rotura del vaso de alabastro por parte de la mujer para derramar el perfume sobre la cabeza de Jesús: «fracto alabastro, effudit super caput eius». Probablemente la relación del pasaje con la Virgen de Campanar esté en el hecho de tener que ser roto el alabastro para ofrecerse como don beneficioso, es decir una alusión a los polvos procedentes de la laceración de la imagen. No obstante, no existe en el libro de Combes una clara mención a este recurso retórico y habría que encontrar algo así en una fuente diferente, probablemente algún sermón.

Bartolomé Combes solamente alude al alabastro como materia en la que fue labrada la imagen. Explica que en el momento del hallazgo, la imagen de la Virgen estaba ennegrecida, y fueron los nobles Melchor y Miguel Sánchez, padre e hijo, junto con el cura Fadrique Villarrasa y su vicario Bartolomé Lull -debería ser importante hacer constar todos estos nombres-, limpiaron la imagen de su inmundicia hasta emerger su materia alabastrina. En la narración del hecho, esta lavación adquiere visos de cierta unción sacra: 


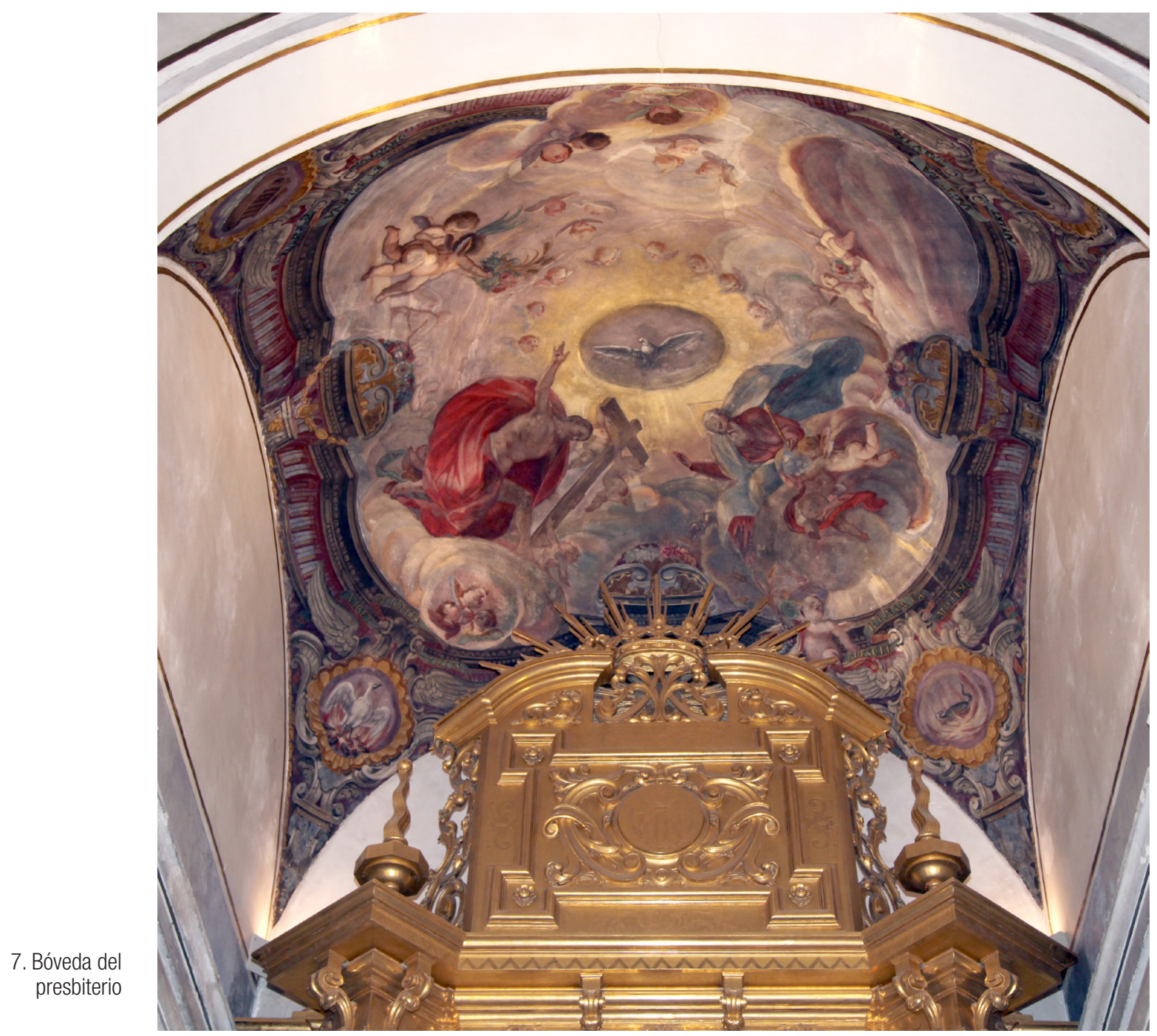

(...) con muy Religioso, quanto devoto asseo, fueron lavando poco à poco con olorosas aguas, sobre vna Almosia grande, ò Fuente de Plata, la superficie toda de la Santa Imagen, que estaba en la humedad del Sitio, y hezes de la tierra, en parte denegrida, hasta dexarla perfetamente blanca, en su primer ser de limpio, y terso ALABASTRO, de que es su Hechura, hermosissima en extremo, y agraciada en todo (1714: 66-67).

\section{Los jeroglíficos del presbiterio}

Especialmente interesante es el programa de los cuatro jeroglíficos que ocupan el tercer tramo, en la bóveda vaída que simula pictóricamente también una cúpula sobre pechinas [7]. En dicha cúpula fingida se despliega una gloria de la Trinidad, la cual orienta su bendición hacia abajo donde se encuentra la imagen de la Virgen de Campanar en la hornacina central del retablo. El programa emblemático se dispone en las cuatro fingidas pechinas de esta bóveda.

Con estas precisiones, podemos pasar al análisis de cada uno de los cuatro jeroglíficos citados, que en su conjunto comunican un discurso verbo-visual, más complejo y mejor fundamentado en la tradición del jeroglífico. Es ello un recurso retórico muy propio del Barroco, verificable sobre todo en las construcciones efímeras: altares exteriores levantados con ocasión de celebraciones tales como las canoni- 


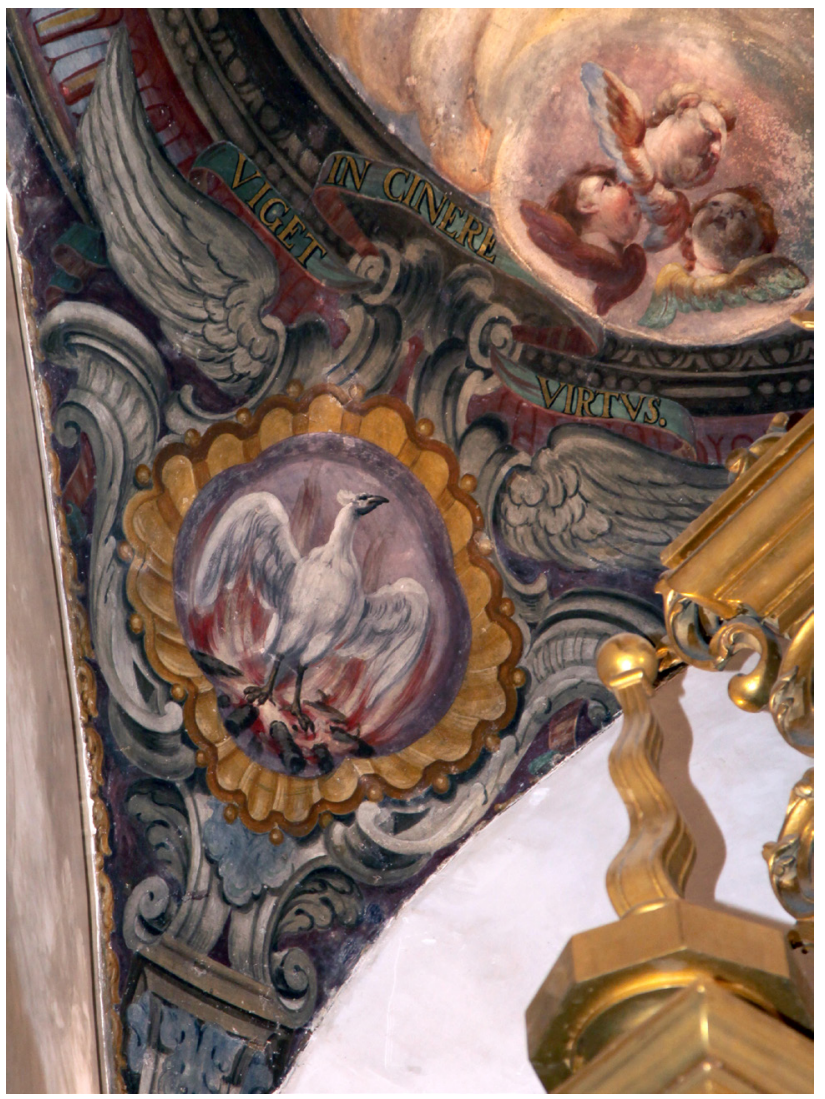

8. El Ave Fénix

zaciones y beatificaciones, exequias, etc. Aquí -y también puede decirse de los jeroglíficos de la cúpula- los tenemos dispuestos en forma de pintura mural y con una perennidad excepcional, ya que hubieran podido ser dispuestos en una construcción efímera.

Jeroglífico l: el Ave Fénix

El discurso visual se inicia en la pechina del lado del Evangelio, de frente, en el testero de la capilla. La pictura de este jeroglífico nos presenta al Ave Fénix en medio de su pira ardiente, con el mote: «Viget in cinere virtus» [Se robustece del vigor de la ceniza] [8].

El mito del fénix es una de las leyendas animalísticas más universales. Su origen cultural se encuentra en el antiguo Egipto desde donde fue importada por los viajeros griegos antiguos, hasta el punto que los rasgos egipcios se diluyen cuando esta leyenda se instaló en la cultura occidental, configurándose en un tópico con un amplio poder evocador, lo que explicará la gran variedad de situaciones a la que se aplica como un recurso retórico e incluso simbólico ${ }^{2}$. Son diferentes las versiones antiguas que se irán configurando sobre el mito. La más cercana a nosotros, por conformar la base principal del desarrollo medieval del mito, es la que mantienen los textos latinos -Ovidio, Plinio, Tácito, Pomponio Mela, Solino, que derivan de las observaciones del Senador Manilio-, según la cual, cuando el ave envejece, se construye un lecho de incienso en donde muere; de su putrefacción nacerá un gusano que pronto acaba asumiendo el aspecto de un renovado fénix y procede a la sepultura de los restos paternos (García Arranz, 2010: 361). En el ámbito de la alegorización cristiana, se desarrollará en dos vertientes: primera, de acuerdo con los Padres de la Iglesia, como símbolo de la resurrección del hombre justo y virtuoso después de la muerte; segunda, la que mantiene el Fisiólogo, enlazando mejor con la tradición egipcia del mito, y la propone como símbolo del sacrificio de Cristo en la Cruz y de su resurrección. La gran popularidad del mito en tiempos medievales hará que se convierta en objeto de alegorizaciones diversas. Nos interesa aquí la relación que pudiera establecerse entre el Ave Fénix y María, y no faltan tampoco fuentes. En concreto, Rufino, a principios del siglo V, comparó la maternidad de María, que concibió por obra del Espíritu Santo, con el fénix: «Y por qué debe ser considerado maravilloso que una virgen conciba, cuando es bien conocido que el Ave de Occidente, a la que llaman fénix, nace y nace de nuevo de tal modo que, sin la intervención de un macho, permanece siendo continuamente una (...)»3. Por lo tanto, existe una tradición ya antigua de la relación del Fénix con María.

La emblemática y otras manifestaciones retóricas y simbólicas se sirven del Ave Fénix como vehículo de diferentes conceptos ${ }^{4}$. Con el Ave Fénix como pictura y por mote el mismo que figura en Campanar: "Viget in cinere virtus", existe ya un precedente en la tradición heráldica como lema en las armas británicas de los Davidson ${ }^{5}$. Ambas cosas están también presentes en la obra El Fenix de Sardeña renace de sus cenizas de Fr. Pedro Andrés de Acorrà, en donde, uno de sus artículos iniciales en que consta la aprobación de la obra, el autor de este, Fr. José de Garate, expresa que «le viene muy apropiado al Autor aquel lema, que puso 
al pie de un Fenix vn Critico: viget in cinere virtus. En estas cenizas descubrirà el Lector muy viua, y encendida la llama de su ingenio entre sus Conceptos (...)» (Acorrà, 1702: s.p.). Este autor sardo, se inspira en el Mondo Simbolico de Picinelli, quien da cuenta de que el académico Govanni Battista Rusca, cuando se celebraron las fiestas religiosas de unas reliquias, dibujó en la iglesia del Santo Sepulcro de Milán, entre otros, el emblema del Fénix con el mismo mote que nos ocupa, para indicar la gran energía que se halla en las reliquias de los santos, la cual tiene una gran influencia en los hombres (1669: lib. IV, cap. 30, p. 180; Skinfill, 2012, 453), concepto del cual se harán eco también los emblemistas jesuitas C. F. Menestrier y J. Boschio [9] ${ }^{6}$.

En cuanto al sentido que tiene este jeroglífico en la Capilla de la Virgen de Campanar, el asunto parece bastante claro, pues no cabe duda de que se está estableciendo un paralelo alegórico entre las cenizas de las que renace el Ave Fénix y los polvos alabastrinos procedentes del raspado de la parte posterior de la imagen. El aludido prologuista de Combes, Fr. Vicente Bellmont, celebra mucho la singularidad de estos polvos: «(...) que se sacan de la mesma Santa Imagen à menudo, sin advertirse en su Bulto disminución alguna, con ser tantos los que se han sacado desde su feliz Hallazgo: En cuyos Polvos, por su indeficiente Perennidad se conoce vna como vital virtud, para qualquiera Bien, que no puede considerarse sin admiración». Este trinitario del Convento del Remedio establece diferentes paralelos retóricos entre dichos polvos y la ceniza, como lo sería la reducción alquímica en donde se halla la ceniza llamada "yesca de la vida» y de la que se formará el oro y la piedra filosofal, advirtiendo también que la memoria de la muerte, sepulcro y ceniza es la mejor yesca de la vida eterna ${ }^{7}$. Continuando con este juego retórico, extenderá el concepto de la ceniza a los venerables polvos de la imagen como «vital yesca» y es en ese contexto como enlazará también con la imagen del Ave Fénix o las cenizas de la palma. He aquí sus palabras:

7 Mas yo lo aplicaría à los POLVOS, y TIERRA de la Imagen de la Virgen de Campanar, que nunca como vitimos pueden ser mirados; pues parece que van renaciendo otros, por mas que se saquen muchos, reconociéndose mejor en ellos, aquella propiedad de la Yesca de la Vida, con que la Imagen se vè como Viviente en lo que su tierra, ò Polvos, al passo que se extraen, van creciendo, sin disminuirse; ò que la Imagen se

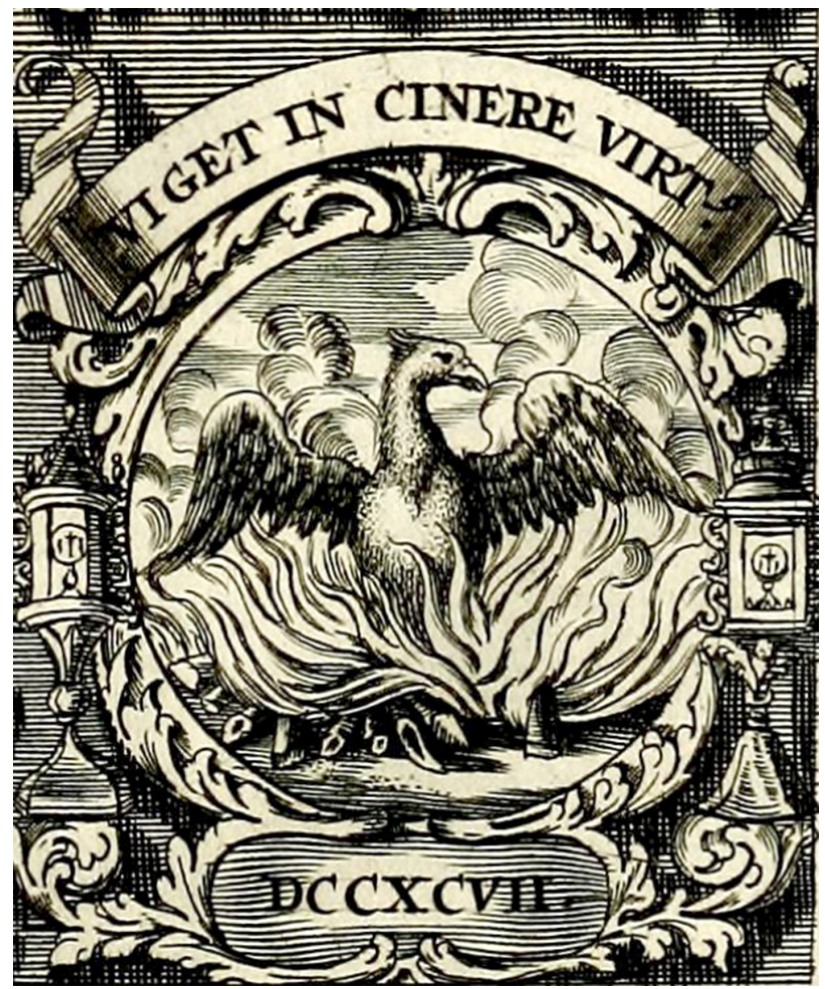

9. El Ave Fénix. J. Boschio

admira como vital Yesca, en lo no menoscabada, por mas que se van sacando POLVOS, y TIERRA en grande suma.

8 Aun por esso discurria yo, que la Virgen en su Imagen, es como la SIEMPRE VIVA, ò PERPETUA, o mejor como la PALMA, que suele equivocarse con el FÉNIX: Porque assi como esta Ave singular en lo viviente, por lo que goza increíbles duraciones, reducida à Polvos, tiene lo admirable de lo Vivo: Assi la Palma, quando mas al parecer la destrozan, y reducen à Polvos lo que de ella quitan, entonces se eleva, y crece mas àzia lo alto: $Y$ esto mesmo ponderava yo alguna vez de nuestra Imagen, para decir, que se lleva la PALMA, y que como FÉNIX, es la Unica entre todas, en lo que tiene de maravillosa por sus POLVOS.

\section{Jeroglífico II: la Salamandra}

El jeroglífico correspondiente a la pechina del testero en el lado de la Epístola tiene por pictura a la Salamandra entre las 


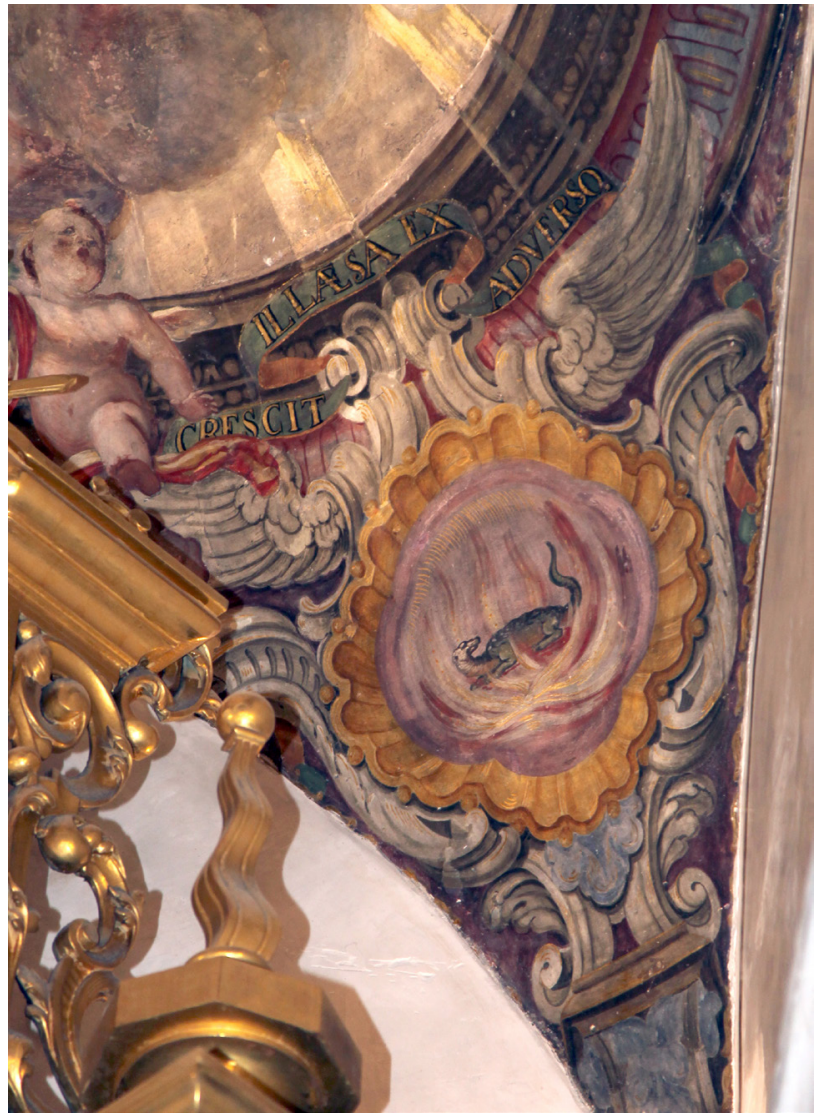

10. La Salamandra

llamas, bajo el mote: "Crescit illaesa ex adverso» [Aumenta ilesa desde su reverso] [10].

Es la Salamandra un animal de carácter fantástico -por más que la zoología científica haya identificado con tal nombre un concreto género- muy relacionada con el fuego ya desde la Antigüedad. Aristóteles la propuso como ejemplo de aquellos animales cuya constitución no se veía afectada por el fuego, en concreto «esta, se dice, apaga el fuego si pasa a través de él» (552b, 15-20; 1992: 285). Claudio Eliano afirmaba que la Salamandra podía vivir dentro del fuego, en medio de la llama "y se aviene a luchar contra ella como con un enemigo», y que en las fraguas, cuando el fuego se debilita, los operarios advierten la acción de este animal en su contra y entonces lo persiguen (NA II, 31; 1984: 133). Plinio sostuvo que era una especie de lagarto pintado de estrellas que aparecía en tiempo de grandes lluvias permaneciendo oculto cuando hacía buen tiempo. Era un animal tan frío que apagaba el fuego con una especie de sanguaza lechosa muy helada que arrojaba por la boca, la cual también eliminaba el cabello y el vello si alcanzaba el cuerpo humano (nat. 10, 67; 1999: 518). A finales del siglo XIII, a pesar de la opinión contraria de Alberto Magno, todavía se pensaba que la Salamandra era resistente al fuego, como Brunetto Latini, para quien la Salamandra vivía en medio del fuego sin dolor ni perjuicio de su cuerpo, y apaga el fuego por su naturaleza (lib. I, CXLVI; 1843: 195). Los bestiarios medievales añadirán otras propiedades ${ }^{8}$. Por tanto, atravesando la Edad Media, estas relaciones fantásticas pasarán a la emblemática como materia de uso retórico.

En el plano de la emblemática, la Salamandra ha generado un conjunto de significados de signo muy diverso. Solamente atenderemos algunos eslabones de la cadena genealógica que nos aproxime al presente jeroglífico de Campanar. Pierio Valeriano afirmó que cuando los antiguos egipcios querían significar a un hombre oprimido por el fuego, sin que este llegue a dañarle, lo hacían con la Salamandra, debido a su cualidad de apagar el fuego mediante su frialdad. Este es su argumento básico sobre la Salamandra, que le permitirá formalizar varios conceptos, de los que nos interesa destacar el intitulado como la «Constancia», que es lo mismo que decir la permanencia inmutable, el fuego de la perfidia no puede perjudicar al que es constante, dice Pierio. Para Filippo Picinelli, en cambio, la evidencia fundamental sobre la Salamandra radica en que se nutre del fuego, y el hecho de apagarlo es interpretado como el ingrato que daña a aquel de quien recibe los beneficios. Por lo tanto estamos ante un complejo código significante y, como en todos los casos, el sentido retórico se orientará según aquello que se pretende. Así, la cualidad de la Salamandra como resistente al fuego, pasó a configurar empresas tales como la de Juan II de Aragón, con el mote «Durabo» [11], significando con ello ser resistente a toda adversidad o violencia externa. En un sentido diferente, tomando la cualidad del fuego como nutriente, las empresas de los reyes de Francia, Carlos VII y Francisco I, con mote «Mi nutrisco", o bien, según los autores «Nutrisco et extinguo» o "Nutrior ex extinguo» se significaban estos como defensores de lo bueno y destructores de lo malo, o bien de alimentarse del buen fuego y apagar el malo ${ }^{9}$. Bastará recordar también que en el castillo de Chambord, la Salamandra de Francisco I está presente en muchas partes.

Para nuestro propósito, en este jeroglífico emblemáti$\mathrm{co}$, se quiere significar la milagrosa cualidad de permanencia 
inmutable y sin mengua de la masa alabastrina de la imagen de la Virgen de Campanar, enlazando con el sentido de constancia o permanencia de Pierio Valeriano, el «Durabo» de la empresa de Juan II, e incluso el "Nutrior et extinguo» de los reyes franceses en el sentido de procurar el bien. Son muchos los matices que podrían aquí entrar en concurrencia. Pero en esencia, parece que el concepto, a partir del mote inscrito en la filacteria superior -Aumenta ilesa en el reverso-, puede ser interpretado en el sentido de la milagrosa permanencia de la masa alabastrina de su materia a pesar del desgaste con ser raspada constantemente en su reverso. La expresión ex adverso, literalmente significa «lado opuesto», es decir "reverso», lo cual es una clara alusión al cuerpo matérico o masa de la imagen, teniendo en cuenta que la imagen de la Virgen de Campanar, como se ha dicho, es un altorrelieve con la parte posterior plana. Así, de acuerdo con el código retórico sobre la Salamandra mantenido en la tradición, el mensaje se fundamenta en el paralelo metafórico de la Salamandra con María: del mismo modo como la Salamandra permanece constante frente a la violencia del fuego, así también la Virgen de Campanar conserva milagrosamente toda su masa sin mengua tras haber socorrido la salud de sus fieles con el rascado de su reverso.

En efecto, la constatación de este prodigio ya está expresa en el manuscrito de Castellví según hemos visto al inicio del presente estudio, quien testimonia el hecho de que "continuamente se saca tierra de la Imagen con abundancia para dar a los enfermos, sin que nunca se conozca menoscabo (...)» (Castellví, 1689: 21). Pero será el párroco de Campanar Bartolomé Combes, quien tras referirse a la altura de la imagen -dos palmos valencianos- y su peso -no llega a sesenta libras de a doce onzas cada una-, especifica que "con ser tan limitada esta su Dimension y Peso, es imponderable la cantidad de Tierra, que hasta oy se ha sacado, y repartido entre los Fieles». Razona a continuación que por razón de una libra cada año -cálculo de lo que ha sido raído a la imagen-, con 117 años no hubiera quedado nada de la imagen: «a no ser vn repetido Prodigio el que sucede, oy por oy, no avia de quedar vn polvo de la Imagen» (p. 94). Este hecho prodigioso es proclamado como conclusión:

Luego viendo el Venerable Bulto de esta santa Celestial Imagen de Maria Santissima de Campanar, en su ser perfecto, sin quiebra, ni disminución notable de su Cuerpo, con tan re-

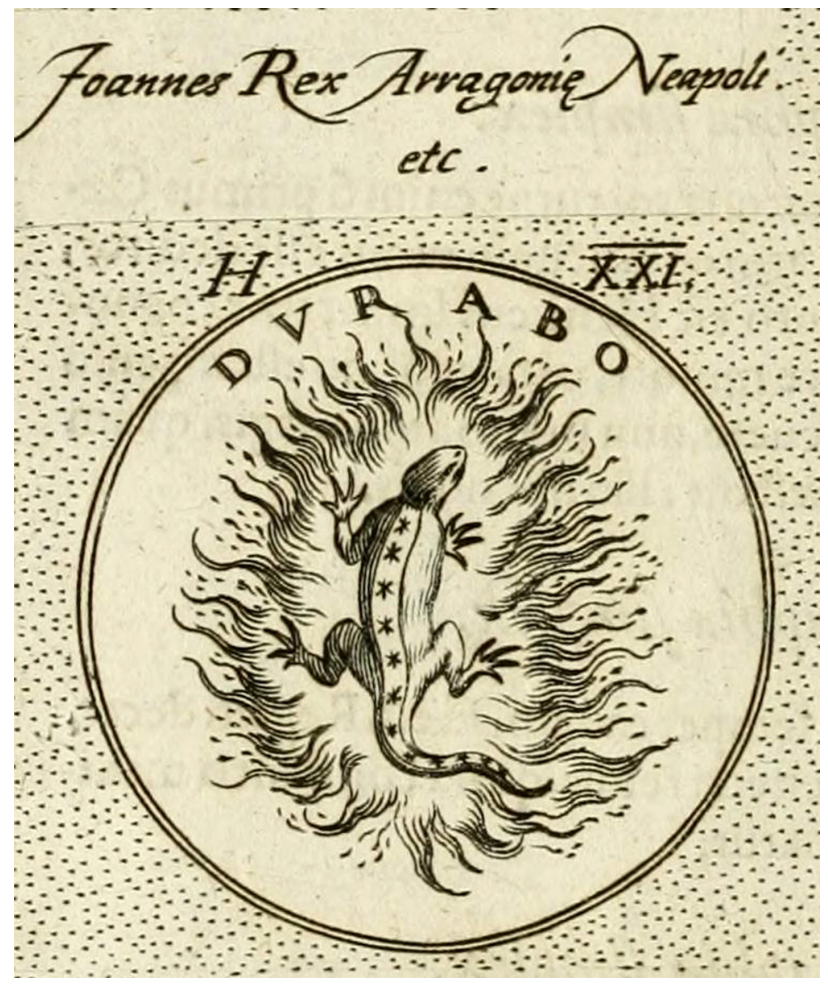

11. La Salamandra, I. Typotius

petida continuación de sacar Tierra, y Polvos tantos años; de necesidad ha de inferirse, que el conservarse entera, parece vn Portento de Portentos, y el mas pasmoso, y mayor de sus Milagros (Combes, 1714: 96).

Jeroglífico III: el Arca de Noé

El Arca de Noé, en medio de las aguas del Diluvio, conforma la pictura del jeroglífico situado en el lado del Evangelio contrario al testero. Por mote leemos: «Fructum et semina confert» [Contiene el fruto y las semillas] [12].

Estamos aquí ante un recurso retórico muy genérico referido a María. El Arca de Noé es un símbolo de María, pues al traer esta al Redentor, trae también la salvación del diluvio, es decir el pecado, en tanto que el diluvio anegó todo el mundo y aniquiló todo a excepción de quienes iban en el arca. Así lo afirmó San Bernardo, quien se refiere a María como "Arca de la Gracia» ${ }^{10}$. El Arca de Noé es un símbolo 


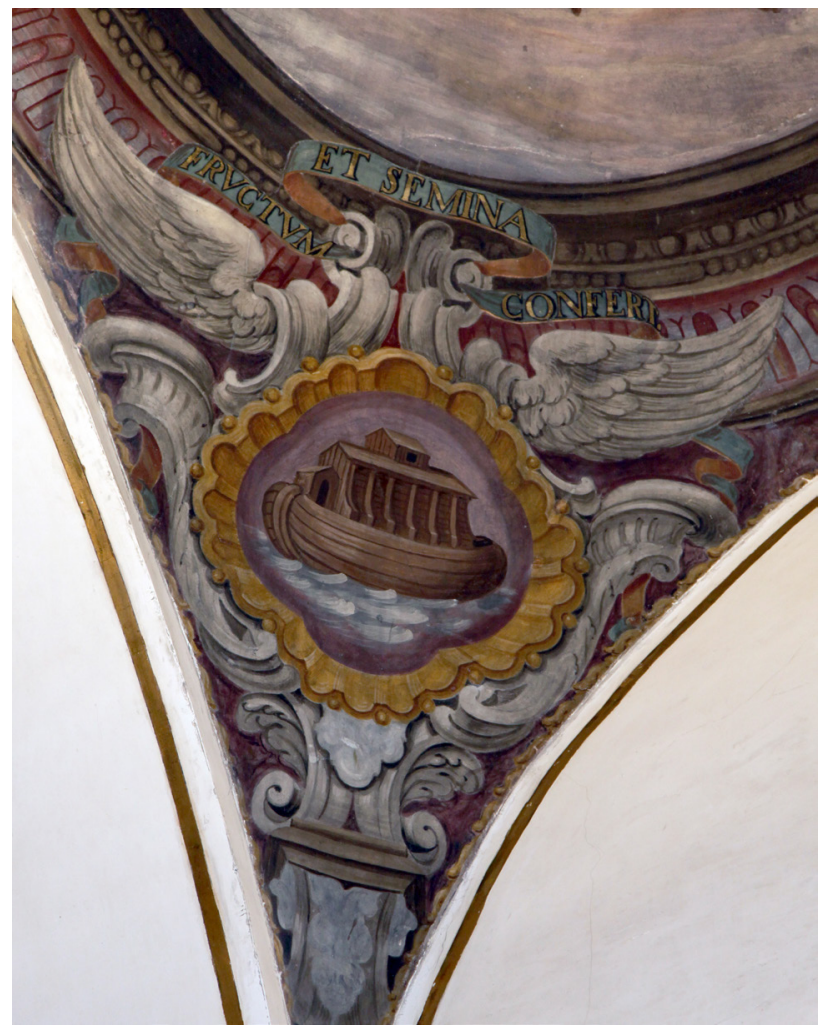

12. El Arca de Noé

bíblico que la exégesis apostólica lo refiere generalmente a la Iglesia, mas es a partir de San Bernardo, fundamentalmente, en que se convierte también en un recurso simbólico mariano.

La emblemática nos presenta el arca de Noé como símbolo de la Iglesia en varios casos. Este tema fue abordado en sus líneas generales y desde sus fuentes patrísticas más representativas en el estudio sobre las Empresas Morales de Juan de Borja (García Mahíques, 1998: 61-64). Entre las manifestaciones emblemáticas consideraremos solamente dos casos: Juan de Borja y Jacob Bosch. El primero nos muestra una empresa con el arca de Noé sobre los montes de Armenia, con el mote «Piorum naufragium», dando a entender que navegando, durante la vida, en la nave de los justos, cuando llegue el naufragio quedaremos como ellos sobre los montes, no así en el profundo del mar y del infierno ${ }^{11}$. Bosch refiere un concepto similar con el mote «Nulla salus extra», en el sentido que no hay salvación fuera de la Iglesia ${ }^{12}$. Con referencia específica a María, Picinelli nos da cuenta de la empresa del Arca de Noé salvada del diluvio, con el mote "Communis discriminis expers", para referirla a la preservación de María del pecado original, para lo cual cita a San Buenaventura y a Hesiquio de Alejandría (Picinelli, 1669: lib. XX, cap. 1, p. 724). Es el sentido también del jeroglífico sobre el Arca de Noé en las Flores de Miraflores de Nicolás de la Iglesia. Este nos ofrece el arca con el simple mote: "Arca Noe» en donde la pictura nos presenta dicha arca flotando en las aguas bajo la lluvia. El epigrama reza: «Si no estuviera bañada / De gracia por dentro y fuera / Todo el mundo pereciera» (1659: 32v). Cita para ello a Hesiquio.

A juzgar por el mote: «Fructum et semina confert» [Contiene el fruto y las semillas], suponemos que este jeroglífico no sigue la tradición de los precedentes emblemáticos citados. Su fuente tampoco parece estar en el libro de Combes. Se trata de algo que encaja mejor en la interpretación de san Bernardo, que pone su atención en María como portadora del Redentor, es decir el fruto que contiene las semillas de la acción redentora, que son sembradas en el corazón de los hombres.

Jeroglífico IV: la Nave

El discurso visual culmina en el lado de la Epístola contrario al testero, cuya pictura consta de un galeón en alta mar, y el mote: «Affert iactura salutem» [El alijo causa la salvación] [13].

Estamos aquí no ante un jeroglífico típico, en el sentido de conformarse a partir de un recurso retórico tal como la metáfora o la alegoría. Pictura y mote no puede ser interpretados por esta vía. Un jeroglífico es siempre un enigma que resulta eficaz como instrumento para que el lector inteligente, o bien el predicador versado en oratoria, pueda con ingenio construir un bello concepto. Aquí pictura y mote desafían al más sagaz que siga la usanza habitual de toda interpretación retórica, y de seguro el resultado sería infructuoso o equivocado. En el presente jeroglífico, gracias a la ayuda del libro de Combes, podemos aproximar una solución verosímil a dicho enigma. Se trata aquí no de una metáfora sino de una alusión a un hecho verídico que debió en su tiempo adquirir renombre, un hecho milagroso a partir de los polvos procedentes de la imagen. La clave interpretativa principal nos la ofrece el mote, en donde iactura, indudablemente debe ser traducido como «alijo», o sea «echar algo por la 
borda». En dicho sentido, hay un hecho milagroso recogido en el libro de Bartolomé Combes que puede explicarlo todo: el hecho milagroso de la calma de la tempestad cuando se arrojan al mar, dichos polvos. Es curioso que el párroco de Campanar se refiera a ello dos veces en su libro. La primera, al hablar de las propiedades prodigiosas del polvo alabastrino, cuando dice: "Los navegantes, que afligidos de las deshechas Tempestades, y Borrascas que el Mar mueve, arrojando en èl porción, por minima que sea, luego calman, y quedan libres del riesgo, y peligro amenazado, hallando en tales Polvos, el Santelmo seguro de los Mares». (Combes, 1714: 91). Más adelante, en el capítulo dedicado a «Favores y Portentos» memorables operados por la virtud de los polvos de la Virgen de Campanar, hay uno de ellos ( $n^{\circ} \mathrm{XXVIII),} \mathrm{en}$ que libra a un devoto de dos horrorosas tempestades marinas. Su nombre es Bautista Cabrelles, quien se embarcó en una faluca hacia las Baleares, pero una tempestad la arrastró a las costas de África, y allá arrojó unos polvos al mar prometiéndole ir a la capilla a darle gracias. Mas arribando al Grao de Valencia, no tuvo tiempo de cumplir su promesa por haber surgido otro negociado. La historia termina así:

Bolviò à embarcarse, y hallándose yà en alta mar, le sobre-

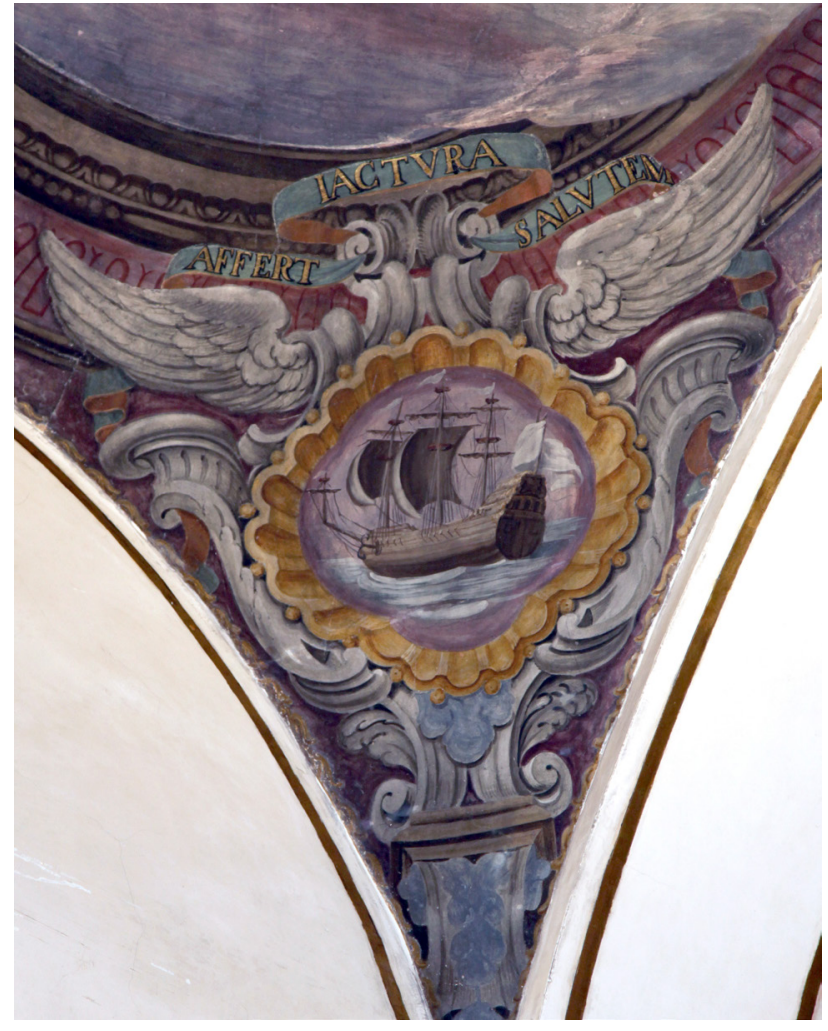

13. El Galeón vino vn Temporal tan recio, que le puso en mayor conflito, que a la vez primera, arrojándole la furia de los Vientos, y desenfrenadas Olas, al mesmo Parage donde la ocasión antecedente quedó encallado: Aquí fue el clamar al Cielo, y à la piedad de la Virgen, ratificando con todas veras su promesa; y echando al Mar vn Papelillo de Tierra, que le quedaba consigo, serenòse en todo, calmò la borrasca, y encaminando la Proa àzia Velencia, arribò à su Playa, y à pie descalço, con

\section{Notas}

1 Puede consultarse el estudio de estas cuatro virtudes en el proyecto de restauración de la Basílica de la Virgen de los Desamparados de Valencia (García Mahíques, 2009: 323-326).

2 Parto de las consideraciones realizadas por García Arranz (2010: 358 y ss.), que son hoy por hoy el más completo estudio sobre el fénix, donde el autor detalla todas sus fuentes, tanto visuales como literarias, así como la variedad de conceptos formulados en el ámbito de la emblemática.

3 Comm. Symb. Apost. 11; PL XXI. Cit. de García Arranz (2010: 365), quien aún advierte que en el siglo XVII, tratadistas como Archibald Simson sigan considerando el fénix como jeroglííco del alumbramiento de María.

4 Para una relación muy completa sobre el impacto del Ave Fenix en la emblemática vid. especialmente García Arranz (2010: 366 y ss.)

5 Vid. <https://canmore.org.uk/collection/1079924> (fecha de consulta: 4-09-2017).

6 Menestrier (1683: 362) dice así: «XXXI. Le bucher du Phenix. VIGET IN CINERE VIRTUS. Quelle vertu dans cette Cendre? Pour les Reliquies d'un Saint». J. Boschio (1702: 55-56) lo referirá también al vigor de las reliquias de los santos: «DCCXCVII. Sanctorum Reliquiae. Phoenix in Cinerem subsidens. L. VIGET IN CINERE VIRTUS». 
7 «5 Mi Eloquentissimo Ortensio, (...) en vn Sermon de Ceniza, dize con su Erudicion profunda: Que los que andan afanados por sacar el Oro, que quieren sea verdadero, y la Piedra Filosofal, que tanto les dà que discurrir (puedase, ò no se pueda hazer, que en esso queda lo Opinativo hasta ahora indeciso) lo cierto es, que los tales dizen, que para conseguir lo que pretenden, han de reducir las materias, de que se valen, à vnas, que llaman vltimos Polvos, ò Cenizas, en las quales se halla vna, que nombran Yesca de la Vida, de que ha de salir lo formal del Oro, y de allí la Piedra Filosofal, que en sì trae tanto bien, como piensa su imaginación». (ib.) / «6 Todo lo aplica mi Erudito Ortensio, al TESORO rico, que se saca de la memoria de la muerte, Sepulcro y Ceniza, en que esta la mejor yesca de la Vida interminable, y gloriosa» (ib.)

8 Es el caso de Guillermo de Normandía, según el cual envenenaba las aguas de los pozos y manantiales donde se sumergía y corrompía los frutos de los árboles a los que subía (Le Bestiaire divin, XXXIII). Añadían otros, como Vincent de Beauvais, que alteraba algunos líquidos alimentarios, o que no era ni macho ni hembra, o que era hermafrodita (Speculum naturale lib. XX, y XLIII). Cit. de Charbonneau-Lassay (1997: II, 814).

9 Salamandra con mote «Durabo», en Typotius (1601: vol. I, hier. XXI, pp. 66-67, tabla 30): «Salamandra sive alitur igne, sive extinguit ignem, ut Plinius tradit, constantiae indicium est Pierio. Et huic suprà, si non subscribit Rex Aragoniae Joannes, ut legis». Salamandra con mote «Mi nustrisco» en Typotius (1601: vol. I, hier. XXIV, pp. 81-82, tabla 37): «Salamandra iterum in foco, sed jam Italicè loquens: Me alo, nutrio. Si de virtute intelligimus, regiè: si de muliere leviter \& amatoriè, utriusq; profectò ingens flamma est, \& illius clarior lux». También en Picinelli (1669: lib. VIII, cap. 17, pp. 400-401): «206 Francesco I. Rè di Francia la portò col cartellone: NODRISCO, ED ESTINGVO, dichiarando con questa pittura se medesimo, e fauoreuole a i buoni, e distruttore de i cattivi (...) Giovanni Rè d'Aragona, se medesimo figurò nella Salamandra, che stà nel fuoco, senza foggiacere à veruna offesa, col motto: DURABO, dichiarandosi in tal guisa insuperabile contra ogni esterna violenza (...)». Vid. así mismo Boschius, J. (1702: 65): «DCCCLXXXI. Adversorum patiens, \& victor. Salamandra in Igne. L. MI NUTRISCO. Sunt alimenta mihi. Franc. I Apud Moyn. / NUTRIOR ET EXTINGUO. Caroli VII. Apud Typotium. / Vel: DURABO. Joannis Regis Aragoniae. Ibid.".

10 "Arca etiem Noe significavit arcam gratiae, excellentiam scilicet Mariae. Sicut enim per illam omnes evaserunt diluvium: sic per istam peccati naufragium. Illam Noe, ut diluvium evaderet, fabricavit: istam Christus (qui est pax nostra et requies), ut humanum genus redimeret, sibi praeparavit» (Be Beata Maria Virgine Sermo; PL CLXXXIV, 1017).

11 Borja (1998: empresa V, p. 22).

12 Boschius (1702: 12): «CL. / Sola ad aeternam Beatitatem Via. Arca Noëmica. L. NULLA SALUS EXTRA, Syll.Men.»

\section{Bibliografía}

ACORRÀ, Fr. Pietro Andrea (1702), El Fenix de Sardeña renace de sus cenizas. Oraciones postumas que dixo el muy R.P.M. Fr. Pedro Andres de Acorrà Hijo de la Ciudad de Caller, y de su Real Combento de N. Señora de Buenayre, del Real Orden de N. Señora de la Merced Redencion de Cautivos (...) Tomo Primero (...), Osorio Martini, Caller.

ARISTÓTELES (1992), Investigación sobre los animales. Tr. y notas de Julio Pallí Bonet, Ed. Gredos, Madrid.

BENITO GOERLICH, Daniel (1982), «Un ejemplo de trasagrario barroco: Nuestra Señora de la Misericordia de Campanar», Traza y Baza, n. ${ }^{\circ} 8$, pp. $67-82$.

BORJA, Juan de (1998), Empresas Morales. Ed. al cuidado de Rafael García Mahíques, Ajuntament de València.

BOSCHIUS, Jacobus (1702), Symbolographia sive De Arte Symbolica sermones septem. Auctore R. P. Jacobo Boschio e Societate lesu (...). Augustae Vindelicorum \& Dilingae, Apud Joannem Casparum Bencard.

CASTELLVÍ COLOMA, Joseph (1689), Catalogo de todas las Santas Imágenes de N. a Señora que dichosamente se veneran en la Ciudad, Villas y Lufares, en el Reyno de Valen. ${ }^{a}$ con una breve descripción del modo, sitio y Lugares en donde se hallaron y tuvieron el origen Isa S. Imágenes, con sus Invocaciones. Manuscrito inédito. Madrid, Biblioteca Real.

CHARBONNEAU-LASSAY, Louis (1997), El Bestiario de Cristo. El simbolismo animal en la Antigüedad y la Edad Media, tr. de Francesc Gutiérrez, José J. de Olañeta Editor, Palma de Mallorca.

COMBES, Bartolomé (1714), Feliz hallazgo del mas rico y celestial tesoro Maria Santissima, aplaudida en su peregrina imagen de Campanar; exhornado con un sacro par de novenas: la una, en obsequio de dicha santa Imagen; y la otra, en Glorias del patriarca san Joseph: que consagra a la Trinidad de la Tierra, Jesus, Maria, Joseph (...), Vicente Cabrera, Valencia.

DE LA IGLESIA, Nicolás (1659), Flores de Miraflores, hieroglificos sagrados, verdades figuradas, sombras verdaderas de Mysterio de la Inmaculada Concepcion de la Virgen, y Madre de Dios Maria Señora nuestra (...), Diego de Nieva y Murillo, Burgos.

ELIANO, Claudio (1984), Historia de los animales, intr., tr. y notas de José María Díaz-Tegañón López, Ed. Gredos, Madrid.

GARCÍA ARRANZ, José Julio (2010), Symbola et emblemata avium. Las aves en los libros de emblemas y empresas de los siglos XVI y XVII, SIELAE y Sociedad de Cultura Valle Inclán, A Coruña.

GARCÍA MAHÍQUES, Rafael (1998), Empresas Morales de Juan de Borja, Imagen y Palabra para una iconología, Ajuntament de València. - (2009), Iconografía e Iconología, volumen 2. Cuestiones de Método, Ediciones Encuentro, Madrid. 
LATINI, Brunetto (1843), Li libres dou Tresor par Brunetto latini publié pour la première fois daprès les manuscrits de la Biliothèque Impériale de la Bibliothèque de l'Arsenal (...) par P. Chabaille. Imprimerie Impériale, París.

MENESTRIER, Claude François (1683), Devises des Princes, Cavaliers, Dames, Scavans, et avtres personnages illustres de l'Europe, ou la Philosophie des Images, tome second, Robert J.B. de la Caille, París.

PICINELLI, Filippo (1669), Mondo Simbolico formato d'imprese scelte, spiegate et illustrate con sentenze, ed eruditioni, Sacre, e Profane (...), nella stampa di Francesco Vigone, Milano.

PICINELLI, Filippo (2012), El Mundo Simbólico. Las Aves y sus propiedades (Libro IV), Ed. Bárbara Skinfil Nogal y Rosa Lucas González, tr. Eloy Gómez Bravo, El Colegio de Michoacán, México.

PLINIO SEGUNDO, Cayo (1999), Historia Natural de Cayo Plinio Segundo trasladada y anotada por el doctor Francisco Hernández (libros primero a vigesimoquinto) y por Jerónimo de Huerta (libros vigesimosexto a trigesimoséptimo) y Apéndice (libro séptimo capítulo LV), Visor Libros, Universidad Nacional de México, Madrid y México.

STRATTON, Suzanne (1988), La Inmaculada Concepción en el arte español, tirada aparte de Cuadernos de Arte e Iconografía, Seminario de Arte «Marqués de Lozoya» de la Fundación Universitaria Española, Madrid.

TYPOTIUS, lacob (1601), Symbola Divina \& Humana Pontificum Imperatorum Regum. Acessit brevis, \& facilis Isagoge lac. Typotii, Pragae. 
